\title{
Жастар жұмыссыздығын төмендетудегі шағын кәсіпкерліктің рөлі
}

\author{
Р.К. Сабирова, А.А Мусаева, А.Р. Тажиденова \\ Х. Досмұхамедов атындағы Атырау университеті
}

Түйін

Ғылыми мақалада Қазақстан экономикасында шағын кәсіпкерлікті ұйымдастырудың экономикалық негіздерін ғылыми-теориялық тұрғыда қарастырып, жастар жұмыссыздығын төмендетуде шағын кәсіпкерліктің рөлін анықтау, шағын кәсіпкерліктің үлесін экономикалық бағалау жүргізілді.

Шағын кәсіпкерлік көрсеткіштерін есептеу әдістемесі осы сектордың Қазақстан Республикасының экономикасына қосқан үлесін бағалауды жүзеге асыру мақсатында шағын кәсіпкерлік қызметін сипаттайтын көрсеткіштерді есептеу үшін ресми статистикалық ақпаратты алудың негізгі аспектілері мен әдістерін айқындайды. Осы әдістеменің мақсаты Қазақстан Республикасында шағын және орта кәсіпкерліктің дамуына талдау жасап, оған экономикалық тұрғыдан баға беру. Бұл әдістемені Қазақстан Республикасы Стратегиялық жоспарлау және реформалар агенттігінің Ұлттық статистика бюросы және оның аумақтық органдары шағын және орта кәсіпкерлік көрсеткіштерін қалыптастыру кезінде қолданады, біз де осы зерттеу жұмысын жүргізуде қолдануды жөн деп таптық.

Зерттеудің құндылығы шағын кәспкерліктің үлесін экономикалық негізді бағалау үшін жан-жақты сандық және сапалық талдау және жастар жұмыссыздығын төмендетуде шағын кәсіпкерліктің рөлін арттыру болып саналады.

Зерттеу нәтижелері - қазіргі экономика жағдайында шағын кәсіпкерлікті дамыту туралы әдіснамалық және теориялық ережелер, сондай-ақ оларды іске асыру жөніндегі ұсыныстар әзірлеу болып табылады.

Авторлар шағын кәсіпкерлік үлесін экономикалық бағалаудың әдіснамалық негізін, жастар жұмыссыздығын төмендетуде, жастарды жұмыспен қамтуда шағын кәсіпкерліктің рөлін анықтап, даму ерекшеліктерін қарастырды.

Зерттеудің мақсаты - Қазақстан экономикасында шағын кәсіпкерлікті ұйымдастырудың экономикалық негіздерін ғылыми-теориялық жағынан қарастырып, жастар жұмыссыздығын төмендетуде шағын кәсіпкерліктің рөлін анықтау, шағын кәспкерліктің үлесін экономикалық бағалау.

Түйін сөздер: кәсіпкерлік, шағын кәсіпкерлік, сандық және сапалық көрсеткіштер, жұмыспен қамту, жастар жұмыссыздығы

\section{Роль малого предпринимательства в снижении молодежной безработицы}

\section{Аннотация}

В статье рассмотриваются научно-теоретические основы организации малого предпринимательства в экономике Казахстана, определена его роль в снижении молодежной безработицы, проведена экономическая оценка доли малого предпринимательства в общем количестве хозяйствующих субъектов.

Методика расчета показателей малы предприятий определяет основные аспекты и методы получения официальной статистической информации для расчета показателей, характеризующих деятельность малого предпринимательства в целях осуществления оценки вклада данного сектора в экономику страны. Целью данной методики являются анализ и экономическая оценка развития малого и среднего предпринимательства в Республике Казахстан. Данная методика применяется Бюро национальной статистики Агентства Республики Казахстан по стратегическому планированию и реформам, Министерством национальной экономики Республики Казахстан и его территориальными органами при формировании показателей малого и среднего предпринимательства. В силу чего мы нашли целесообразным ее применение при проведении данного исследования.

Цель исследования-научно-теоретическое рассмотрение экономических основ организации малого предпринимательства в экономике Казахстана, определение роли малого предпринимательства в снижении молодежной безработицы, экономическая оценка доли малого предпринимательства в численности хозяйствующих субъектов.

Результатом исследования стала разработка методологических и теоретических положений о развитии малого предпринимательства в условиях современной экономики, а также предложений по их реализации. Ценность исследования заключается во всестороннем количественном и качественном анализе доли малого предпринимательства и повышения его роли в снижении молодежной безработицы.

Ключевые слова: предпринимательство, малое предпринимательство, количественные и качественные показатели, занятость, молодежная безработица 


\section{The role of small businesses in reducing youth unemployment}

\section{Annotation}

The scientific article considered the scientific and theoretical foundations of small business organization in the economy of Kazakhstan, identified the role of small business in reducing youth unemployment, and conducted an economic assessment of the share of small business in the total number of economic entities.

The methodology for calculating small business indicators defines the main aspects and methods of obtaining official statistical information for calculating indicators that characterize the activities of small businesses in order to assess the contribution of this sector to the country's economy. The purpose of this methodology is to analyze and evaluate the economic development of small and medium-sized businesses in the Republic of Kazakhstan. This method is used by the Committee on statistics of the Ministry of national economy of the Republic of Kazakhstan and its territorial bodies in the formation of indicators of small and medium-sized businesses, and we found it appropriate to use in this study.

The value of the study lies in a comprehensive quantitative and qualitative analysis of the share of small business and the increasing role of small business in reducing youth unemployment.

The research results include the development of methodological and theoretical provisions on the development of small business in the modern economy, as well as proposals for their implementation.

The authors have defined the methodological basis for the economic assessment of the share of small business, the role and features of small business development in reducing youth unemployment and youth employment.

The purpose of the study is a theoretical consideration of the economic foundations of small business in economy of Kazakhstan, defining the role of small entrepreneurship in reducing youth unemployment, economic assessment of the share of small entrepreneurship number of entities.

Keywords: entrepreneurship, small business, quantitative and qualitative indicators, employment, youth unemployment

\section{Kipicпе}

Шағын кәсіпкерлік - әрбір елдің экономикалық өсімінің даму қарқынын, құрылымын және жалпы ұлттық өнімнің сапасын көрсететін маңызды секторлардың бірі. Экономикасы дамыған елдерде ЖҰӨ жартысына жуығы осы шағын кәсіпкерлік үлесіне тиесілі, Қазақстанда бұл небәрі - 29,5 $\%$.

Шағын кәсіпкерлік секторының алатын үлесіне елдегі құрылатын жаңа жұмыс орындарының 75-80\% тиесілі. Дегенмен жаңа бастаған кәсіпкерлер бірқатар мәселелерге тап болады. Зерттеу ұстанымын қолдана отырып, біз Қазақстанның, соның ішінде Атырау облысының шағын кәсіпкерлік үлесін экономикалық тұрғыдан бағалауды жөн көрдік.

Дүниежүзі елдерінің барлығын шарпып, 14 миллионнан астам ауру мен 600 мыңнан астам өлім жағдайлары орын алған COVID-19 пандемиясы әлеуметтік-экономикалық проблемаларға әкеп соқтырды, атап айтсақ, жаппай жұмыссыздықтың орын алуы, табыс көзінің болмауы және бизнестің күйреуі, ірі мұнай компанияларының шығынға ұшырап, қаржылық қиындықтарға кездесуі [1]. Ұзаққа созылатын әлемдік экономикалық дағдарыс әлемдік экономикаға біраз уақытқа шейін әсер етуі ықтимал.

Осындай экономикалық дағдарыс кезінде ел экономикасын көтеретін бірден бір жол шағын кәсіпкерлікті дамыту, шағын кәспкерлік субъектілерін қолдау.

Шындығында шағын кәсіпкерлік қазіргі кезде нарықтық экономиканың негізі болып саналады. Экономикалық бағалау арқасында ipi кәсіпкерлік құрылымымен салыстырғанда шағын кәсіпкерліктің бірқатар артықшылықтарын айтуға болады.

Оларды атап өтсек, біріншіден, нарықтық таңдауда еркіндікті қамтамасыз ету арқасында, экономиканы құрылымдық жағынан қайта құруға жағдай жасайды. Екіншіден, қосымша жұмыс орынымен қамтамасыз ету арқылы қоғамдағы жұмыспен қамтылу деңгейін жоғарылатады. Үшіншіден, шығындардың ақталу жылдамдығы арқасында кәсіпкерліктің табыстылығын арттырады. Төртіншіден, тұтынушы нарығындағы өзгерістер мен тұтынушының нарықтық мінез-құлқының өзгеруіне сәйкес сұранысқа жылдам жауап береді. Шағын кәсіпкерлік салалық және аумақтық монополизмге қарсылық таныта отырып, бәсекенің кеңеюіне және нарықтың тауарлар мен қызметтерге толығуына мүмкіндік береді. Тұрғындардың жұмысбастылығы саласында әлеуетке ие болып отырып, ірі кәсіпкерлік саласының өндірістік және технологиялық ерекшеліктеріне сәйкес қолданыла алмайтын жұмыс күшін өндіріске тартады. Яғни үй шаруашылығындағы әйелдердің, мүгедектердің, зейнеткерлердің, студенттердің, жастардың сонымен қатар, негізгі жұмыс уақытынан кейін қосымша жұмыс істеуге тырысатын жұмыскерлердің жұмысбастылығын қамтамасыз етеді. Ел экономикасында шағын кәсіпкерліктің қалыптасуы мен дамуы экономикалық өсімді жоғарылатуға ықпал етеді[2].

Жастар жұмыссыздығын азайтуда шағын кәсіпкерліктің рөлін түсінуде оның экономикалық мәнін, нарықтық қатынастар жағдайында, 
ұлттық экономика қалыптасуындағы түрлі меншік формасындағы оның қандай орын алатындығын жақсы білу керек.

Экономикалық бағалауда қолданылатын шағын кәсіпкерлік көрсеткіштерін есептеу әдістемесі халықаралық стандарттарға сәйкес қалыптастырылатын және «Мемлекеттік статистика туралы» Қазақстан Республикасының 2010 жылғы 19 наурыздағы Заңына сәйкес бекітілетін статистикалық әдіснамаға негізделеді [3].

Зерттеу жұмысының ғылыми жаңашылдығы жастар жұмыссыздығын төмендетуде жастар кәсіпкерлігін дамытудың рөлін көтеруге, жастардың өзін-өзі жұмыспен қамту жағдайына мемлекет тарапынан қолдау керектігі негізделіп, ұсыныстар берілді.

Біздің зерттеуіміздің практикалық маңыздылығын айтатын болсақ, жастар жұмыссыздығын азайтуда, жаңа жұмыс орындары көбейеді деген үмітпен шағын кәсіпкерлік қызметінің дамуына ықпал ету, шағын кәсіпкерліктің даму көрсеткіштерін сандық және сапалық тұрғыдан қарастыруда зерттеу нәтижелерін мемлекеттік органдар, кәсіпкерлікті қолдау орталықтары қолдана алады.

\section{Әдебиеттерге шолу}

Шағын кәсіпкерлік туралы көптеген әдебиеттерде зерттелген. Заңда белгіленген белгілері бар нарықтық экономиканың белгілі бір субъектілері жүзеге асыратын қызмет шағын кәсіпкерлік (шағын бизнес) деп танылады [4]. Шағын кәсіпкерлік кәсіпорынның салыстырмалы түрде шағын мөлшері мен шаруашылық қызметінің ауқымын ғана білдірмейді, сондай-ақ ерекше тәуекелдік және инновациялық негізге, толық экономикалық жауапкершілікті ала отырып, жұмсалған капитал бірлігінен барынша кәсіпкерлік табыс алу үшін ұдайы өндіруді басқарудың және ұйымдастырудың дербестендірілген және икемді тәсілдеріне міндетті түрде сүйенеді.

Бұл сапалық жағдай ерекше маңызды, алайда экономикалық әдебиеттерде және практикада да шағын кәсіпкерлік көбіне сандық көрсеткіштер негізінде анықталған, бұл «шағын кәсіпкерлік», «шағын бизнес», «шағын (ұсақ) және орта кәсіпорындар» ұғымдарын нақты анық етіп көрсетуге ықпал етпейді.

Бұл ұғымдардың айырмашылығы неде және оларды бөлудің қажеттілігі бар ма? Мысалы, шетелдік ғалымдар К.Грэй және Дж.Стэнуорт шағын кәсіпорынның ешқандай әмбебап анықтамасы барлық міндеттер үшін жеткілікті болуы мүмкін емес деп санайды. Терезелерді жуушы, екі қызметкері бар тәуелсіз дүкен, бір жалдамалы жұмысшы және трактормен немесе қандай да бір басқа жабдықтармен жабдықталған үш жүз акр жері бар фермер, елу қызметкері бар тігін фабрикасы - олардың барлығы трансұлттық корпорациялардан ерекшеленетін жалпы проблемаларға кездеседі [5]. Бұл авторлар шағын кәсіпорынды ipi кәсіпорындардан бөліп тұратын әмбебап анықтамасының болуы міндетті емес деп санайды.

Шағын бизнес дамыған сайын ол өсудің бес сатысынан өтеді, олардың әрқайсысының өзіндік ерекшеліктері бар. Өйткені өсудің бір сатысынан екіншісіне өту өзгерістерді талап етеді, ол қандай да бір дағдарыспен бірге жүреді[6].

Цифрландыру дамыған сайын кәсіпорындар, әсіресе шағын және орта кәсіпорындар, өнімнің өмірлік циклінің қысқаруына және бәсекеге қабілеттілікті сақтау үшін инновациялық өнімдерді үздіксіз енгізудегі ақпараттық технологиялардың өсіп келе жатқан рөліне байланысты қысымға ұшырайды.

Өсіп келе жатқан бәсекелестік қысым мен өнімнің өмірлік циклінің төмендеуіне байланысты инновацияларға қысым пайда болады, ондай қысымды шағын және орта кәсіпорындар жалғыз өзі жеңе алмайды. Тиісінше, бәсекелестер, жеткізушілер немесе клиенттер сияқты сыртқы серіктестермен серіктес болуды ұсынады[7].

Мысалы, шағын және орта бизнесті анықтау үшін А. Колесников формальды және формальды емес амалдарды бөледі [8]. Шағын және орта кәсіпорындардың (фирмааралық, салалық, салааралық, өңіраралық және халықаралық деңгейлер) қызметін статистикалық байқау және салыстыру; шағын кәсіпорындарды қолдаудың мемлекеттік бағдарламаларын әзірлеу (жергілікті, өңірлік, федералдық, мемлекетаралық деңгейлер); салық салу (жергілікті және федералдық деңгейлер) жатады; білім (бизнес білім беру - шағын фирманы басқару, экономикалық білім беру шағын және орта бизнес экономика секторы ретінде); зерттеулер (шағын және орта бизнес кәсіпорындарын, басқару стилін, нарықтық ерекшеліктерді және т.б. зерттеу). Екінші (бейресми) тәсілге: шағын бизнесті қолдаудың мемлекеттік бағдарламаларын әзірлеу, білім беру және зерттеулер жатады.

\section{Әдіснама}

Мақалада талқыланған мәселенің әдіснамалық негізі осы мәселеге қатысты шетелдікжәнеотандықғалымдардыңзерттеулері болып табылды. Шағын кәсіпкерліктің артықшылықтары мен кемшіліктері, жастар 
жұмыссыздығын азайтуда шағын кәсіпкерлікті дамытудың бағыттары зерттелінді. Шағын кәсіпкерлікке қатысты көзқарастар және әлеуметтік-еңбек қатынастарындағы жаңа үрдістер қарастырылды. Шағын кәсіпкерліктің шаруашылық субъектілер жалпы санындағы үлесін экономикалық бағалау жасалды. Қазақстан Республикасы Стратегиялық жоспарлау және реформалар агенттігінің Ұлттық статистика бюросы статистикалық мәліметтері негізінде талдау жасалды.

\section{Нәтижелер мен талқылау}

Экономикалық бағалау арқасында ipi кәсіпкерлік құрылымымен салыстырғанда шағын кәсіпкерліктің бірқатар артықшылықтарын және кемшіліктерін айтуға болады [9].

Әлемдік тәжірибе көрсетіп отырғандай, шағын кәсіпкерлік экономиканың тұрақты дамуына ықпал ете отырып, үлкен рөл атқарады, өйткені оған белгілі бір артықшылықтар тән. Шағын кәсіпкерлікті дамытудың шетелдік және отандық тәжірибесін талдай отырып, ipi бизнеспен салыстырғанда оның мынадай артықшылықтарын көрсетуге болады:

- шаруашылық жүргізудің жергілікті жағдайларына неғұрлым жылдам бейімделу;

- шағын кәсіпкерлік субъектілері ісқимылдарының үлкен тәуелсіздігі;

- қабылданатын шешімдерді қабылдау мен орындаудағы икемділік және жеделділік;

- қызметті жүзеге асыру кезінде салыстырмалы түрде төмен шығыстар, әсіресе басқаруға арналған шығындар;

- жеке тұлға үшін өз идеяларын іске асыруға, өз қабілеттерін көрсетуге үлкен мүмкіндік;

- бастапқы капиталға деген қажеттіліктің неғұрлым төмендігі және өнімге және өндіріс үдерісіне жергілікті нарықтардың талаптарына жауап ретінде тез өзгерістер енгізу қабілеті;

- меншікті капиталдың салыстырмалы түрде жоғары айналымдылығы және т.б.

Шындығында шағын кәсіпкерлік бүгінгі таңда нарықтық экономиканың негізі болып саналады.

Шағын бизнестің тиімділігін қамтамасыз ететін маңызды артықшылығы қызметкерлердің өзара алмасуы болып табылады. Қызметкерлер арасындағы атқаратын қызметтерді белгілі түрде шектеу кезінде шағын ұжым үшін өзара көмек және бір-біріне қолдау, ал қажет болған жағдайда қайталау және өзара алмастыру тән [10].

Шағын кәсіпкерлікті ұйымдастыру үшін, әдетте, негізгі қаражатқа ірі салым қажет емес екенін атап өту қажет. Бұл артықшылық көптеген жаңа бастаған кәсіпкерлерді өз ісін бастауға тартады және шығарылатын өнімнің, жұмыстардың, қызметтердің өзіндік құнына оң әсер етеді.

Сонымен қатар шағын кәсіпкерліктің бірқатар кемшіліктері мен проблемалары да бар:

- тәуекелдің жоғары дәрежесі, үлкен шығынға ұшырап, жабылып қалу қаупі, себебі көп нәрсе сыртқы ортаның ықпалына байланысты;

- капиталдың жинақталу мүмкіндігінің төмендігі, оның иелері өндірісті кеңейту үшін өз қаражатының аз ғана бөлігін бөле алады;

- шағын кәсіпкерлік саласы шектеулі, қор және ғылымды қажетсінетін өндірістерге енгізу қиын;

- шағын кәсіпорындарға өзінің маркетинг қызметін, дилерлік желіні ұйымдастыру қиын, шығарылатын өнімнің номенклатурасы шектеулі және ірі өндіріспен бәсекелестікте қиындықтар туындайды.

Күнделікті бизнесте жаңа бизнесмодельдерін жасақтау мен енгізуге уақыт бөлінбейді [11].

Көптеген елдерде кәсіпкерлер саяси үрдістерге қатысуды белсенді іздейді, партияларда саяси қозғалыстарды қалыптастырып, олардың мүдделерін қорғайды.

Шағын кәсіпкерліктің атқаратын қызметтерінің маңыздылығын мойындау барлық елге жуық шағын кәсіпкерлікті дамыту мен қолдау бойынша ұлттық деңгейде де, жергілікті деңгейде де үлкен көңіл бөлінеді.

Бір он жылдықтан екінші бір онжылдыққа индустриалдық-экономикалық дамуда шағын кәсіпкерлік рөлі тарихи тұрғыдан ерекшеленеді. Мысалы, Оңтүстік Кореяда негізгі индустрияландыруда ipi өнеркәсіптік конгломеранттар алда болып келді, тек кейін ғана шағын кәсіпкерлікке көңіл аудара бастады. Басқа елдерде, мысалы, Тайваньда шағын кәсіпкерлік экономикалық және индустриалдық дамудың қозғаушы күші болды, кейіннен бұл транұлттық корпорацияға дейін өсті. Сонымен бірге бірқатар елдерде, мысалы, Үндістанда iрi импорталмастырушы өндірістердің дамығандығы байқалды, ол сонымен қоса отбасылық және микрокәсіпкерлік дамумен қатар жүрді.

Әлемдік экономикада ұзақ уақыт болуына қарамастан, шағын кәсіпкерліктің немесе шағын бизнестің нақты бір анықтамасы жоқ. Бұл ұғымдарды түрлі ұстаныммен қарастыруда, әрбір елде түрлі критерийлер қолданылады. Бір жағынан, нақты әмбебап критерийлердің болмауы түрлі елдердегі шағын кәсіпкерліктің даму деңгейін салыстырмалы бағалауда қиындық туғызады. Екінші жағынан, бар ерекшеліктер объективті, әрбір мемлекетті жеке алғанда 
оның әлеуметтік-экономикалық дамуымен, мәдени және тарихи ерекшеліктерімен негізделеді.

Шағын кәсіпорындарға жатқызылатын белгілері немесе критерийлері барынша түрліше. Алайда соның ішінен біз әлемдік тәжірибеде жиі қолданатындарын атап көрсеткен жөн деп санадық. Оларға жататыны: кәсіпорында - жұмыспен қамтылған жұмыскерлер саны, кәсіпорында - активтер құны, тауар айналымы немесе шығарылатын өнім көлемі.

Қазақстанда шағын кәсіпкерлік секторының бейіні ҚР Кәсіпкерлік кодексіна сүйенеді, Қазақстан Республикасының Кәсіпкерлік Кодексі 2015 жылы 29 қазанда қабылданып, 2016 жылғы қаңтардан бастап күшіне енді. Ол бұрын қолданыста болған «Жеке кәсіпкерлік туралы» КР Заңын алмастырды. Кодекс Қазақстан Республикасында кәсіпкерліктің еркіндігін қамтамасыз ететін құқықтық, экономикалық және әлеуметтік жағдайлар мен кепілдіктерді айқындайды, кәсіпкерлік субъектілері мен мемлекеттің өзара іс-қимылына, оның ішінде кәсіпкерлікті мемлекеттік реттеу мен қолдауға байланысты туындайтын қоғамдық қатынастарды реттейді.

Қызметкерлердің орташа жылдық санына және орташа жылдық табысына қарай кәсіпкерлік субъектілері мынадай санаттарға жатады: шағын кәсіпкерлік субъектілері; орта кәсіпкерлік субъектілері; ipi кәсіпкерлік субъектілері.

Осының ішінде біздің зерттеу нысанымыз шағын кәсіпкерлік субъектілері. Заңды тұлға құрмаған дара кәсіпкерлер және қызметкерлерінің орташа жылдық саны 100 адамнан аспайтын және орташа жылдық табысы республикалық бюджет туралы заңда белгіленген және тиісті қаржы жылының 1 қаңтарында қолданыста болатын үш жүз мың еселенген айлық есептік көрсеткіштен аспайтын кәсіпкерлікті жүзеге асыратын заңды тұлғалар шағын кәсіпкерлік субъектілері болып табылады.

Зерттеу объектісі шаруашылық жүргізуші субъектілердің төрт түрінің жиынтығы болып табылады: шағын және орта кәсіпкерлікке жататын жеке кәсіпкерлер, шаруа немесе фермер қожалықтары және заңды тұлғалар.

Статистикалық қызметте субъектілерді шағын және орта кәсіпкерлікке (бұдан әрі - ШОК) жатқызу үшін Қазақстан Республикасының 2015 жылғы 29 қазандағы Кәсіпкерлік кодексіне сәйкес қызметкерлердің орташа жылдық санының критерийі ғана пайдаланылады.
Шағын кәсіпорындардың қызметі туралы жалпымемлекеттік статистикалық байқаулар іріктеп зерттеу әдісімен жүргізіледі.

ШОК статистикасы бойынша деректерді қалыптастыру үшін ақпараттық база:

1) шағын және орта кәсіпкерлікке жататын заңды тұлғалардың қызметі туралы жалпымемлекеттік статистикалық байқаулардың алғашқы статистикалық деректері;

2) ауыл шаруашылығы статистикасы бойынша шаруа немесе фермер қожалықтары өнімдерінің жалпы шығарылымы туралы ресми статистикалық ақпарат;

3) статистикалық бизнес-тіркелімнің деректері;

4) әкімшілік көздердің әкімшілік деректері;

5) тұтыну бағаларының индекстері.

ШОК субъектілерінің қызметін экономикалық бағалау үшін мынадай көрсеткіштер қалыптастырылады:

1) тіркелген ШОК субъектілерінің саны;

2) жұмыс істеп тұрған ШОК субъектілерінің саны;

3) жұмыс істеп тұрған ШОК субъектілеріндегі қызметкерлер саны;

4) ШОК субъектілері өндірген өнімнің, орындалған жұмыстардың және көрсетілген қызметтердің көлемі;

5) ШОК субъектілері өндірген өнімнің, орындалған жұмыстардың және көрсетілген қызметтердің нақты көлем индексі.

ШОК субъектілерінің қызметін сипаттайтын көрсеткіштер облыстар (аудандар) және экономикалық қызмет түрлері бойынша тоқсандық кезеңділікпен қалыптастырылады.

«Тіркелген ШОК субъектілерінің саны» және «ШОК жұмыс істеп тұрған субъектілерінің саны» көрсеткіштері СБТ (статистикалық бизнес тіркеу) деректері бойынша қалыптастырылады.

Шағын кәсіпкерлік субъектілерінің іскерлік белсенділігін бағалаумен байланысты зерттеу бағыттарының қалыптасуы түрлі әдістердің жасалуына әкелді, ол әдістер кәсіпкерлік қызметтің қарқындылығын анықтауға арналған. Бағалауда көптеген әдістемелердің болуы және олардың көпқырлығы, шағын кәсіпкерлік субъектілерінің өзіндік ерекшеліктерінің бар болуына қарай зерттеуді жалпы ерекшелендіретін қиындықтар бар. Шағын кәсіпкерлік субъектілерінің іскерлік белсенділігін бағалаудың әдістемелік ұстанымы экономикалық зерттеудің бірнеше деңгейінде қалыптасты: халықаралық немесе ел деңгейінде, аймақтық деңгейде, жергілікті және шағын кәсіпкерлік субъектісі деңгейінде. 
Осындай икемділік себепті шағын кәсіпкерлік субъектілерін бағалау, соның ішінде оның іскерлік белсенділігін бағалау статистикалық мәліметтердің тез ескіруімен қиындайды.

Екіншіден, шағын кәсіпкерлік субъектілер үшін кәсіпкерлік активтер табыстылығының төмендеуі, еңбектің жоғары қарқындылығы, меншікті қаражаттың шектеулігі, соның салдарынан үлкен тәуекелділік, онда бұндай шағын кәсіпкерлік субъектілеріне қызметтің ресми емес түрі тән болады, сондықтан берілген объект қиын қол жетімді статистикалық бақылау мәліметтерінен тұрады. Бұндай шағын кәсіпкерлік субъектілерінің ерекшеліктерінің салдары оның іскерлік белсенділігін бағалауға шектеуге әкеледі. Шағын кәсіпкерлік субъектілерінің іскерлік белсенділігін бағалау салыстырмалы тұрғыда тек жақында ғана жүзеге аса бастады.

Халықаралық және стратегиялық деңгейде шағын кәсіпкерлік субъектілерінің іскерлік белсенділігін бағалау ғаламдық мониторинг форматында шағын кәсіпкерліктің жағдайы мен даму үдерісі салыстырмалы талдаудан көрінеді.

Аймақтық деңгейде шағын кәсіпкерлік субъектілерінің іскерлік белсенділігін бағалау бірқатар ерекшеліктерге ие: біріншіден, аймақ деңгейінде әдістемелердің көпшілігі авторлық тұрғыда және тұрақты түрде практикалық жүзеге асырылмайды.

Екіншіден, аймақтық деңгейде ғана кәсіпкерлікті бағалау жан-жақты көрінеді. Үшіншіден, әдістеме түрлі деңгейде жасалғандықтан, олардың көпшілігі бағаланатын аумақтың аймақтық ерекшеліктерін ескермейді.

Аймақтық деңгейде шағын кәсіпкерлік субъектілерінің іскерлік белсенділігін бағалауда сандық параметрлердің серпінін бағалау анық көрінеді. Ол үшін келесідей сандық көрсеткіштер қолданылады:

- саны, жылына 100 мың халыққа тіркелген шағын кәсіпорындардың өсімі /қысқаруы;

- саны, алдыңғы жылмен салыстырғанда шағын кәсіпорындарда жұмыс жасайтын жұмыскерлердің орташа тізім санының өсуі/ қысқаруы;

- алдыңғы жылмен салыстырғанда шағын кәсіпорындар айналым көлемі, сондай-ақ оның өсуі/төмендеуі;

- алдыңғы жылмен салыстырғанда шағын кәсіпорындағы негізгі қорға салынған инвестицияның өсуі/төмендеуі.

Атырау облысы ШОК субъектілерінің өнім шығаруы (салыстырмалы бағада) 2020 жылғы қаңтар-қыркүйекте 2019 жылғы қаңтар-қыркүйекпен салыстырғанда 29,4\%ға төмендеді, жұмыспен қамтылғандар саны 3,6\%-ға және жұмыс істеп тұрған субъектілер саны 1,7\%-ға ұлғайды. Сондай-ақ 2020 жылы қазанда олардың белсенді жұмыс жасап тұрған саны 49,9 мыңы немесе 86,6\% белсенді қызмет жүргізеді(1-кесте). 2009 жылдан бастап тіркелген ШК субъектілерінің саны тұрақты өсімді көрсетеді.

Атырау облысында жұмыс істеп тұрған барлық шаруашылық жүргізуші субъектілердің санындағы жұмыс істеп тұрған ШК субъектілерінің үлесін қарастырсақ, облыстағы жұмыс жасап тұрған жеке кәсіпкерлердің 77,3 пайызы осы шағын кәсіпкерлікке қатысты екен, ал Атырау облысы негізінен мұнай-газ өнеркәсібіне бағытталғандықтан, облыста ауыл шаруашылығы саласы емес, басқа салаларжақсы дамыған, ал шаруа қожалықтары көбіне ауыл шаруашылығының шаруашылық субъектісі болып табылады, облыстағы оның үлесі басқа еліміздің өңірлерімен салыстырғанда төмен (6,1%), бұл түсінікті.

Кесте 1 - Атырау облысы ШОК субъектілерінің құрылымы және олардың қызметінің көрсеткіштері, 2020 жыл

\begin{tabular}{|l|c|c|c|c|c|c|}
\hline & $\begin{array}{c}\text { Саны, } \\
\text { бірлік* }\end{array}$ & $\begin{array}{c}\text { Алатын } \\
\text { үлесі, } \\
\%\end{array}$ & $\begin{array}{c}\text { Жұмыспен } \\
\text { қамтылғандар } \\
\text { саны, адам* }\end{array}$ & $\begin{array}{c}\text { Алатын } \\
\text { үлесі, } \\
\%\end{array}$ & $\begin{array}{c}\text { Өнім (тауарлар, қызмет } \\
\text { көрсетулер) шығарылым, } \\
\text { млн. теңге** }\end{array}$ & $\begin{array}{c}\text { Алатын } \\
\text { үлесі, \% }\end{array}$ \\
\hline $\begin{array}{l}\text { Барлық белсенді ШОК } \\
\text { субъектілер саны, } \\
\text { соның ішінде }\end{array}$ & 49997 & 100 & 126690 & 100 & 1608277 & 100 \\
\hline ШОК кәсіпорындар & 8312 & 16,6 & 61558 & 48,6 & 1537577 & 95,6 \\
\hline Дара кәсіпкерлер & 38661 & 77,3 & 60722 & 47,9 & 52924 & 3,2 \\
\hline $\begin{array}{l}\text { Шаруа немесе фермер } \\
\text { қожалықтары }\end{array}$ & 3024 & 6,1 & 4410 & 3,4 & 17776 & 1,10 \\
\hline $\begin{array}{l}\text { Ескерту - Қазақстан Республикасы Стратегиялық жоспарлау және реформалар агенттігінің Ұлттық } \\
\text { статистика бюросы / шww.stat.gov.kz } \\
* 2020 \text { жылдың 1 қазанына } \\
\text { **2020 жылдың қаңтар-қыркүйегіне }\end{array}$ \\
\hline
\end{tabular}


Дегенмен бұл үдеріс республика көлемінде де осындай: экономикалық қызмет аралығында шағын кәсіпкерлік субъектілерінің ішінде өнім өндірукөлемі бойыншашағын кәсіпорындардың алатын үлесінің жоғары екендігін көріп отырмыз (95,6\%). Ал шаруа қожалықтары мен фермерлік шаруашылықтардың өнім өндіру құрылымындағы алатын үлесі небәрі 1,1\% ғана. Бұл деген елімізде ауыл шаруашылығындағы өндіріс орындарының, агро бизнестің әлі де жақсы дамып кете алмай тұрғандығының себебі деп пайымдаймыз.

1-суретте Қазақстан Республикасының ЖІӨ-дегі шағын және орта кәсіпкерлік үлесінің көрсеткіштері келтірілген.

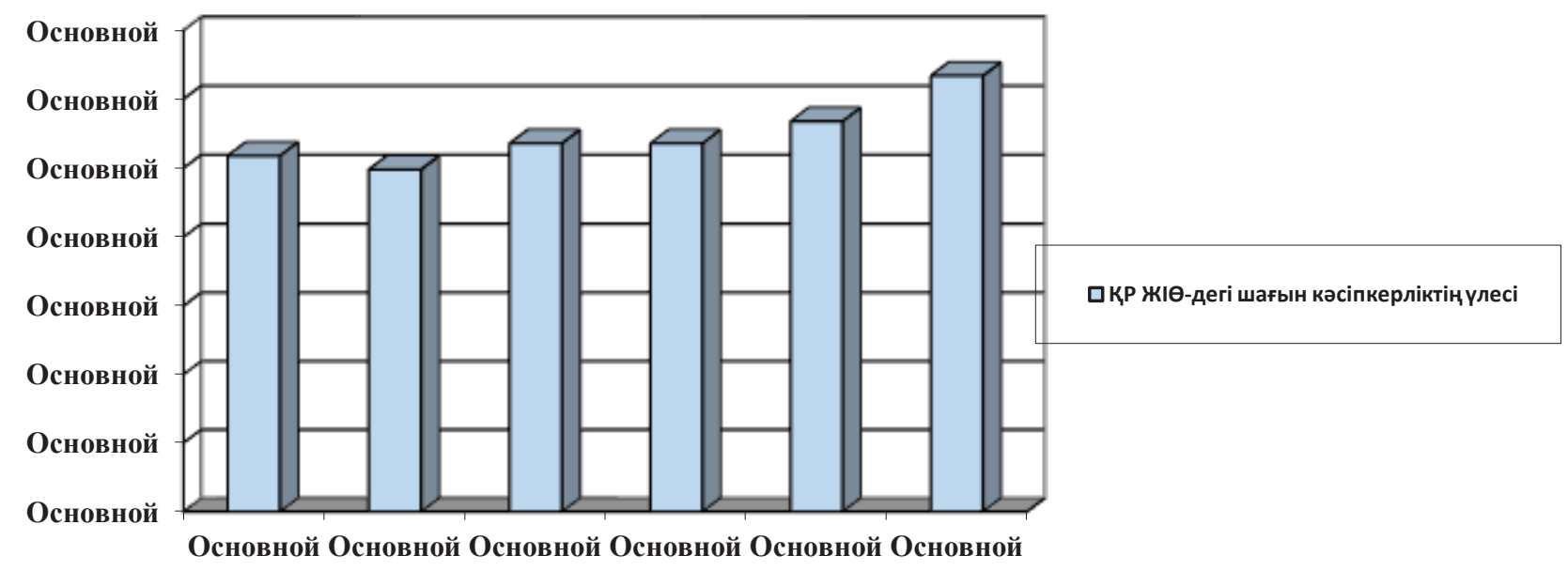

Ескерту - Қазақстан Республикасы Стратегиялық жоспарлау және реформалар агенттігінің Ұлттық статистика бюросы / https://taldau.stat.gov.kz/ru/NewIndex/GetIndex/19824647

Сурет 1 - Елдің ЖІӨ-дегі шағын және орта кәсіпкерліктің үлесі, \%

Шағын кәсіпкерлік дағдарыс әсерінен деп болжауға болады, аутсайдер болған ШК экономика өсімінің жетекші драйверлерінің біріне айналды, алайда оның жоғары көрсеткіштері оның қызметінің жеткіліксіз айқындылығын назарға ала отырып, күмән тудырады[12].

1-суреттен елдің ЖІӨ-дегі шағын кәсіпкерліктің үлесі соңғы 6 жылда 25,9-дан 29,5\% - ға дейін, яғни 4 есе дерлік өсті. 2019 жылы ШК белсенді субъектілері санының динамикасы оң өсу үрдісін сақтап қалды (2014 жылмен салыстырғанда 29,5\%-ға).

Жастардың өзекті мәселелері ішінде жұмыссыздықтың өсуі алда тұр. Дамыған елдерде, мысалы, АҚШ-та қазіргі пандемия кезінде 7,7 млн жастар жұмыссыз [13]. Ұлыбританияда 2020 жылдың мамыр айында жұмыссыздық бойынша жәрдемақы алуға өтініш берген жастар саны алдыңғы айлармен салыстырғанда 109\%-ға өскен. Еуропада жұмыссыздық саны біршама өскен, әсіресе Италия, Испания, Францияда[14].

Қазақстанда жастар жұмыссыздығы 2019 жылы 2 тоқсанда 3,7\%, ал пандемия кезінде 2020 жылдың 2 тоқсанында 4\% болған, өткен кезеңмен салыстырғанда 0,3\%-ға өскен.
Жастарды жұмыспен қамтуда кәсіпкерлікті, өз бетінше жұмыспен қамтуды дамыту керек.

Өз бетінше жұмыспен қамтылғандарды жастар бойынша да қарастыратын болсақ, олардың саны да жыл сайын азайып келеді (2-сурет).

Жастар көбіне жалақысы тұрақты жалдамалы жұмыскер болуды, мемлекеттік қызметте жұмыс жасағанды қалайды, жастар кәсіпкерлікпен айналысуда тәжірибенің жоқтығынан, қиындықтан қорыққандықтан, ақша қаражатының және капиталдың болмауынан өз бетінше жұмыспен қамтылу бағытын қаламайды[15].

Оны 2-суреттегі мәліметтерден байқауға болады. Бүгінде өзіндік жұмыспен қамтуды, жастардың шағын кәспкерлікпен айналасуын қолдау қажет. Қазақстандағы даму институттары мен венчурлік қорлар жобаны жүргізетін сауатты инженерлер мен менеджерлердің жетіспеушілігін атап өтуде. Ұлттық инновациялық жүйені табысты дамыту үшін даму институттары қазіргі заманғы инфрақұрылымды - ғылыми орталықтарды, технопарктерді құру және оларды дамыту қажет. Сонымен қатар зияткерлік ұлтты қалыптастыру жөніндегі міндет инфра- 
құрылымдық негіздерді құруға да, адами капиталға да инвестиция салуды көздейді, Біздің ойымызша, венчурлық индустрия
Қазақстан Республикасы экономикасының инновациялық секторының жылдам ілгерілеуін ынталандыратын пәрменді элемент болуға барлық негіз бар.

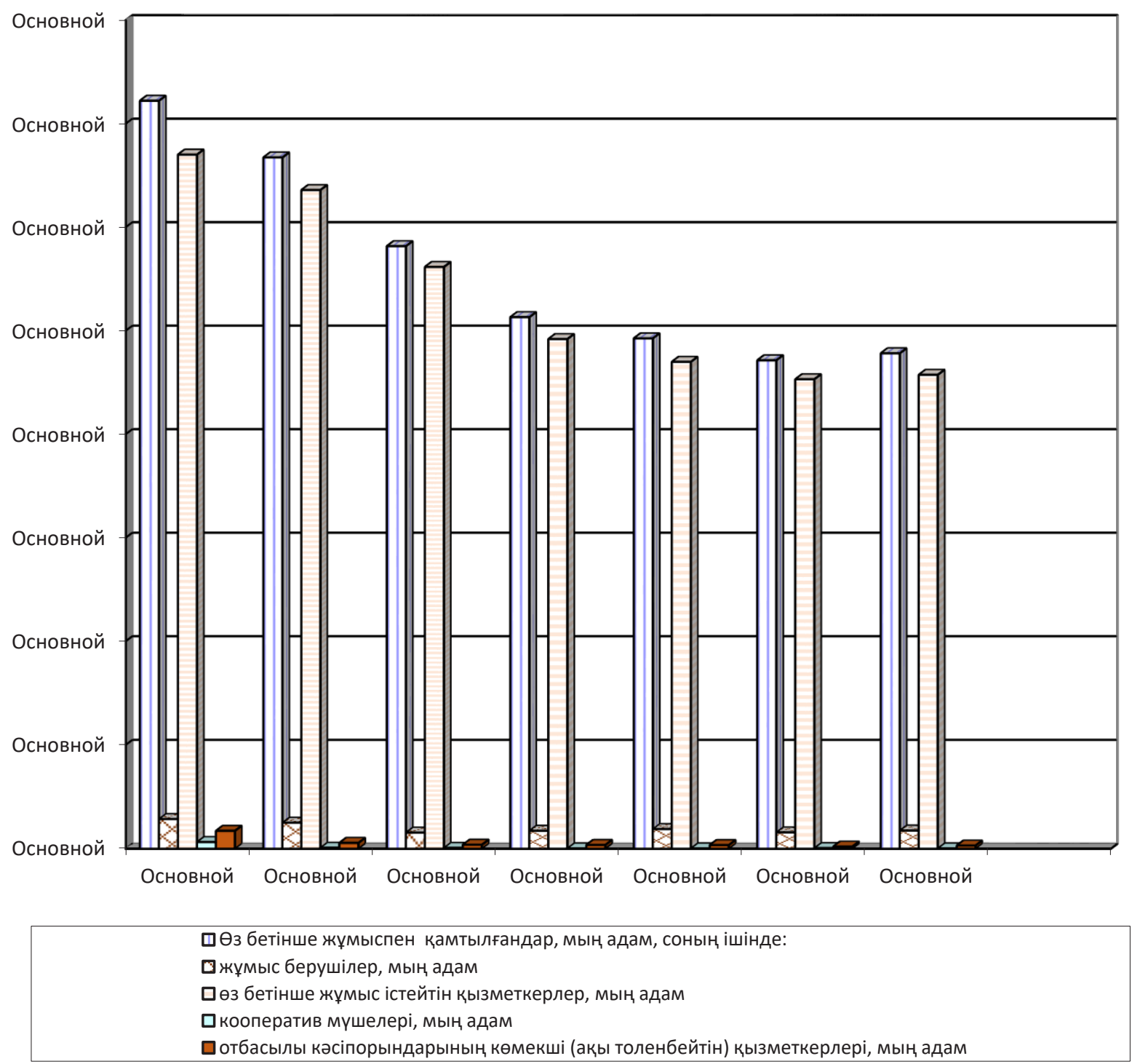

Ескерту - Қазақстан Республикасы Стратегиялық жоспарлау және реформалар агенттігінің Ұлттық статистика бюросы / www.stat.gov.kz

\section{Сурет 2 - ҚР бойынша 2013-2019 жылдардағы өз бетінше жұмыспен қамтылған жастар саны (15-28 жас аралығында)}

Қазіргі уақытта Атырау облысында кәсіпкерлікті қолдау және дамыту мақсатында, сондай-ақ өнімді жұмыспен қамтуды қамтамасыз ету үшін «2017-2021 жылдарға арналған өнімді жұмыспен қамтуды қамтамасыз ету мен жаппай кәсіпкерлікті дамыту бағдарламасы», «Бизнестің жол картасы-2020» бағдарламалары іске асырылуда. Шағын және орта кәсіпкерлік қызметінің маңызды көрсеткіші олардың елдің жалпы ішкі өнімін (бұдан әрі - ЖІӨ) қалыптастыруға қосқан үлесі болып табылады $[16,17]$.

Бүгінде Қазақстанда ауыл шаруашылығын мемлекеттік қолдауға, әсіресе қаржылай қолдауда үлкен жұмыстар жүргізіліп, мемлекеттік бағдарламалар жүзеге асырылуда. Дегемен ауыл шаруашылығында шағын кәсіпкерліктің дамуы, әсіресе агробизнес жағдайы әлі де сын көтермейді, оның өзі бөлек зерттеуді талап етеді[18]. 
Қазіргі уақытта ұлттық экономика түп тамырымен қайта өзгеруде, жаңа форматқа көшуде. Осы өзгерістер шеңберіндегі бір стратегиялық бағыт - елдің ЖІӨ-гі шағын кәсіпкерліктің қосқан үлесін 2050 жылға қарай 50\%-дан кем болмауға жеткізу. Шағын кәсіпкерліктің дамуына кедергі келтіретін анықталған мәселелер басқарудың мемлекеттік және жергілікті деңгейде бірқатар шаралардың атқарылуын талап етеді[19].

Шағын кәсіпкерлік субъектілерінің дамуының басымдық бағыттары тез өзгермелі нарық жағдайында орта мерзімді перспективаға дәл болжам жасау үшін қажет.

Шағын кәсіпкерлікті қолдаудың ең перспективті түрлерінің мысалдары бизнесинкубатор және бизнес-акселератор болып табылады.

Бизнес-инкубатор - бұл бастапқы кезеңде жаңадан құрылған немесе жас кәсіпорындарды тиімді қолдауға бағытталған аймақтық экономикалық дамуға көмек көрсету құралы. Инкубаторлар көбінесе кәсіпкерлер үшін желілер құруда маңызды рөл атқарады [20, 21].

Әрқашан кәсіпкерлерге кеңсе және өндірістік үй-жайларды, ішінара техникалық жабдықтарды тиімді шарттармен жалға беруге, сондай-ақ тиісті қызметтерді көрсетуге (кеңестер, қолдау және инфрақұрылым) басты назар аударылады. Бизнес-инкубаторлар алғашқы қиын жылдардағы жас кәсіпкерлер үшін жақсы бастама жасайды. Жалпы, бизнесинкубаторлар өздерінің жеке ісін құратын және бастаушы кәсіпкерлер үшін бастапқы жағдайлар мен өмір сүру мүмкіндіктерін жақсартуға көмектеседі. Сонымен қатар, осындай аяғына нық тұрған шағын кәсіпкерлердің осындай орталығына кіру барлық қатысушылардың пайдасына қызмет ете алатын кәсіпкерлік қызмет тәжірибесімен бөлісуге мүмкіндік береді. Бизнес жеделдеткіштері бизнесжобаларды ертерек қолдауға арналған үлгі болып табылады, бірақ олар инкубаторлардан айтарлықтай ерекшеленеді. Бизнес- инкубатор бірінші кезекте кеңсе үй-жайларын және инфрақұрылымдық компаниялар ұсынатын қызметтер жиынтығын (жарнама, заңгерлік көмек) көрсетеді.

Бизнесті жеделдету бағдарламаларының маңызды артықшылығы - бұл тәжірибемен және оқытумен бірге, сонымен қатар шағын инвестициялармен («жобаны өмірлік қолдау» деп аталатын) әртүрлі нысандағы тәлімгерлік. Бизнес-тренингтер, кеңсе инфрақұрылымы, ақпараттық қолдау, инвесторлармен қарымқатынастар, Demo Day және Investor Day (командалар өз жобаларын әлеуетті серіктестерге, инвесторларға, баспасөзге ұсынатын іс-шаралар), сондай-ақ «экожүйе» де бар. Бір-бірімен үнемі байланыс орнататын өршіл кәсіпкерлер мен мамандардың көпшілігі жеделдету бағдарламаларына қатысады, «гараж» атмосферасын жасайды және кәсіби байланыстар орнатады. Кейбір мәліметтерге сәйкес, тәлімгерлерге ақы төленбейді, олар өздерінің кәсіби идеялары мен тәжірибелерін алға жылжыту мен таратудан қанағат алады. Алайда, кейбір жағдайларда тәлімгерлер стартаптың пайдасының 1-ден 6\%-на дейін бөліседі. Стартаптар үшін негізгі көмек - бұл сәтті кәсіпкерлермен байланыс: құрылымды қалай құру керек, инвестицияларды қалай алу керек, команда қалай құруға болады және не дайын болу керек. Акселератордағы бүкіл оку процесі үш айдан алты айға дейін созылады. Осы уақытта командалар «өседі» және тәлімгерлерге мұқтаждықты тоқтатады немесе «өледі».

«Х.Досмұхамедов атындағы Атырау университеті» коммерциялық емес акционерлік қоғамында кәсіпкерлік білім беру бойынша дамыту жөніндегі іс-шаралар белсенді іске асырылуда.

Барлық бакалавриат мамандықтарына «Кәсіпкерлік негіздері және стартап менторы» деген пән енгізіліп, оқытылуда. Сонымен қатар пәнаралық модуль ретінде барлық экономикалық және заң мамандықтарына «Бизнес-жоспарлау» пәні енгізіліп, оқытылуда.

Студенттердің кәсіпкерлік ойлауын қалыптастыру және әртүрлі аспектілерінде практикалық дағдыларды дамытуда экономика және құқық факультетінде бизнес-мектеп ашылды. Бизнес-мектеп білім алушылардың сабаққа қызығушылығын арттырады және оған қатысушылардың өз мамандығын алуға ынталандыру үшін аналитикалық, коммуникабельді және шығармашылық қабілеттерін дамытуға ықпал ететін тренингтер өткізіледі.

Бизнес-құрылымдармен және бизнес қауымдастықтармен одан әрі ынтымақтастықты дамыту, кәсіпкерлік құзыреттілікті қалыптастыруға, дипломдық жұмыстар мен өндірістік практикаға басшылық етуге бағытталған пәндер бойынша оқу процесіне жетекші маман-практиктерді тарту, сондай-ақ бизнес-бағдарланған пәндерді оқу-әдістемелік сүйемелдеуді бірлесіп әзірлеу үшін бизнессектор кәсіпорындарында мамандар даярлатын кафедралардың филиалдарын құру және бұрыннан бар филиалдардың жұмысын жандандыру.

Стартаптар, бизнес-жобалар конкурстарына студенттер, магистранттар, жас ғалымдардың қатысуын белсенді ету және 
ғылыми және ғылыми-техникалық қызмет нәтижелері жобаларын коммерцияландыру шеңберінде білім алушыларды Enactus, Эразмус+ халықаралық әлеуметтік кәсіпкерлікті дамыту бағдарламаларына қатыстыру, оның ішінде әлеуметтік-бағытталған және коммерциялық бизнес жобалары іске асыруға қатыстыру.

Зерттеу барысында жастар кәсіпкерлігінің күшті және әлсіз жақтары анықталды, күшті жақтары:

- жоғары бастамашылық белсенділік, инновациялық ойлау;

- жоғары Ұтқырлық, ұстанымдар икемділігі, жаңа нарықты игеру бойынша тез жауап беру;

- өндіріс пен нарықтың өзгермелі талаптарына сәйкес өздерінің кәсіпкерлік білімдерінің жүйелі жаңару мүмкіндіктерінің жоғары деңгейі;

- жастардың тәуекелге тез баратындығы.

Жастар кәсіпкерлігінің әлсіз жақтары:

- әлеуметтік тәжірибенің азығы;

- іскерлік белсенділіктің жоқтығы;

- экономикалық заңдар мен тетіктерді қолданудың практикалық дағдыларының әлсіздігі;

- бастапқы капиталды қалыптастыру мәселесі;

- бизнес сферасы мен басқару-билік құрылымдарында жеке қатынастардың жеткіліксіздігі;

- бюрократтық құрылымдар әрекетінен қорғалмау;

- «көлеңкелі» кәсіпкерліктің белсенді тұрғыда дамуы.

Осылайша, азақстан экономикасын жаңғырту жағдайында индустриялық-шикізат экономикасынан «білім экономикасы» моделіне көшу стратегиялық басымдық болып табылады. Бұл индустриялық үрдістерді тереңдетуге, оң әлеуметтік-экономикалық және техникалық-технологиялық өзгерістерге ықпал ететін жас инновациялық белсенді кәсіпкерлердің легін қалыптастыру қажеттілігін өзектендіреді. Сондықтан кәсіпкерлікті дамытуда жастардың бизнес-белсенділігін дамыту және кәсіпкерлікке оқытудың инновациялық бағдарламаларын қалыптастыру бойынша одан әрі жұмыс істеу қажет.

\section{Корытынды}

Сонымен қысқаша қорытынды жасайтын болсақ, қарастырылып отырған зерттеуде «шағын кәсіпкерлік субъектілерінің іскерлік белсенділігінің бағасы» төрт шешуші сандық көрсеткішті талдау жыл аяғында зерттеушілерге шағын кәсіпкерліктің дамуы жөнінде өзіндік қорытынды жасауға мүмкіндік береді.
Белсенді ШК субъектілері санының қарқынында ұйымдық-құқықтық нысандар бөлінісінде соңғы бес жылда келесі беталыстар бақыланады:

1. ШК кәсіпорындарының саны 2014-2019 жж. ішінде тұрақты артып отырды. 2019 жылы шағын кәсіпкерлік кәсіпорындары 2014 жылмен салыстырғанда 5 есе өскен.

2. Тіркелген дара кәсіпкерлер саны 2018 жылмен салыстырғанда 2019 жыл соңына 0,3\%ға қысқарды, ал 2014 жылмен салыстырғанда 2019 жылы 8,2\%-ға қысқарды;

3. Шаруа-фермерлік қожалықтарының саны шағын кәсіпкерлік кәсіпорындары және дербес кәсіпкерлер санымен салыстырғанда мардымсыз. 2014 ж. Атырау облысында шаруафермерлік қожалықтары белсенді әрекет етті, олардың саны 2014 жылдан бастап өсе бастаған, 2019 жылы 2014 жылмен салыстырғанда 35,3\%-ға артқан.

Жастар жұмыссыздығы, жастарды жұмыспен қамту, жастардың өзін-өзі жұмыспен қамтуы, жастар кәсіпкерлігі мәселесі мәселелік-салдарлық және елдің әлеуметтікэкономикалық дамуының сапа көрсеткіші. Сондықтан жастар жұмыссыздығы мәселесін шешуде шағын кәсіпкерліктің рөлін көтеру үшін елімізде кешенді және жүйелі шаралар алынуы тиіс.

Қазақстанның әрбір аймағы жаппай кәсіпкерлікті, оның ішінде отбасылық кәсіпкерлікті дамыту жөніндегі шаралар кешенін ұсынуы тиіс. Ең алдымен білім беру жүйесінің рөлі өзгеруі керек. Біздің міндетіміз-білім беруді экономикалық өсудің жаңа моделінің орталық буынына айналдыру. Оқу бағдарламалары жастардың сыни ойлау қабілетін және ақпаратты өз бетінше іздеу дағдыларын дамытуға бағыттау қажет.

Шағын кәсіпкерлік туралы алыс шетел, ресейлік және отандық ғалымдардың ғылыми еңбектеріне шолу жасалды, осы еңбектердің нәтижесінде шағын кәсіпкерліктің жастар жұмыссыздығын азатудағы рөлі нақтыланды.

Қазіргі уақытта шағын және орта бизнесті мемлекеттік қолдау проблемасын зерттеудің өзектілігі ерекше өткір тұр, өйткені бұл экономиканы жаңғырту міндеттерін шешуде осы сектордың рөлін жандандыру қажеттілігімен байланысты. Жалпы, шағын және орта кәсіпкерлікті қолдау саласында жүргізіліп жатқан мемлекеттік саясат мемлекеттік бағдарламалар шенберінде барлық бағыттар бойынша іске асырылуда. Қазірдің өзінде бизнес-ортаны дамытуда ілгерілеушілік байқалады, бизнес-климат дәйекті түрде жақсаруда, жастар кәсіпкерлігін дамытуда «Бизнестің жол картасы- 2025» мемлекеттік 
бағдарламасына сәйкес мына шаралар әрі қарай жалғасу керек:

-моноқалалар, шағын қалалар мен ауылдық елді мекендерде жас кәсіпкерлерінің жаңа бизнес-бастамаларын қолдау;

-экономиканың басым секторларында кәсіпкерлік қызметін жүзеге асыратын жастарды салалық қолдау;

-жас кәсіпкерлердің валюталық тәуекелдерін төмендету;

-кәсіпкерлікпен айналысатын жастарды қолдаудың қаржылық емес шараларын жандандыру.

Зерттеудің қаржыландыру көзі. Ғылыми мақала ҚР БҒМ ҒК ғылыми және ғылыми-техникалық жобаларды гранттық қаржыландыру жобасы шеңберінде орындалды (Грант АР08956950).

\section{Пайдаланылган әдебиеттер тізімі}

1. Amankwah-Amoah J., Khan Z., Woodc G. COVID-19 and business failures: The paradoxes of experience, scale, and scope for theory and practice// European Management Journal. — 2020 - - https:// doi.org/10.1016/j.emj.2020.09.002

2. Макыш С.Б., Урузбаева Н.А. Шағын және орта бизнесті дамытудағы Қазақстанның қаржылық ахуалы // Л.Н.Гумилев атындағы ЕҰУ хабаршысының экономика сериясы.- 2019.- № 2.-. Б. 127-132.

3.”Мемлекеттік статистика туралы” Қазақстан Республикасының 2010 жылғы 19 наурыздағы Заңы [Электронный ресурс]. - Режим доступа: adilet.zan. kz.

4. Токсанова А.Н.Основы предпринимательской деятельности: учебник. - Астана: [Print-S], 2007 . $-478 \mathrm{c}$.

5. Small business management in the New Europe / Ed. by A.A. Gibb, M. Rebernik. - Maribor: Ekon. inst, 1994. $-750 \mathrm{p}$.

6. Timothy Bates. Entrepreneur Human Capital Inputs and Small Business Longevity//The Review of Economics and Statistics. - 1990. - Vol. 72. No. 4. - P. 551-559

7. Busch Ch.., Barkema H. Planned Luck: How Incubators Can Facilitate Serendipity for Nascent Entrepreneurs Through Fostering Network Embeddedness// Entrepreneurship Theory and Practice. $\quad-\quad 2020 \quad$-https://doi. org/10.1177/1042258720915798

8. Колесников А., Колесникова Л. Малый и средний бизнес: эволюция понятий и проблема определения // Вопр. экономики. - 1996. - № 7. C. $46-58$.

9. Hippel E., Lead Users. An Important Source of Novel Product Concepts// Management Science. - 1986. - 32. - No. 7. - P.791-805.

10. Beck T., Demirguc-Kunt A. Small and Medium-size enterprises: Access to finance as growth constraint// Journal of Banking \& Finance. -2006. - Vol. 30. -No. 11. -P. 2931-2943.

11. Daxhammer K., et al. Development of a Strategic Business Model Framework for Multi-Sided Platforms to Ensure Sustainable Innovation in Small and Medium-Sized Enterprises// Procedia Manufacturing. -2019. -Vol. 39. - P. 1354-1362

12. Сабирова Р.К., Джумаева А.К., Уталиева P.С. Өзін-өзі жұмыспен қамту: теориялық негіздері мен мәселелері// Экономика: стратегия и практика. -2020. -№ 1 (15). -Б. 113-125.

13. COVID-19 leads to dramatic unemployment, young people suffer the most. - URL: https://news. cgtn.com/news/2020-05-29/COVID-19-leads-todramatic-unemployment-young-people-sufferthemost-QSUcPNPJ0Q/index.html (Дата обращения 28.10.2020)

14. Государственная программа поддержки и развития бизнеса «Дорожная карта бизнеса - 2025»// http://adilet.zan.kz/rus/docs/P1900000968

15. Доскалиева Б.Б. Экономика малого и среднего бизнеса города Алматы: проблемы и перспективы / Б.Б. Доскалиева и др. // Вестн. КазНУ. Серия экономическая. - 2017. -№ 1. -С. 379-385.

16. Программа развития продуктивной занятости и массового предпринимательства на 2017-2021 годы, утверждена Постановлением Правительства Республики Казахстан от 29 декабря 2016 года № 919 [Электронный ресурс]. - Режим доступа: adilet.zan.kz.

17. Программа «Дорожная карта бизнеса 2020». Постановление Правительства РК № 301 от 13 апреля 2010 г. [Электронный ресурс]. - Режим доступа: adilet.zan.kz.

18.Дарибаева А.К., Курманкулова Н.Ж., Карбетова Ш.Р. Развитие массового предпринимательства в Казахстане//Вестник КарГУ. Серия «Экономика». - 2018. - № 3(91). - С. 173-178.

19. Урузбаева Н. А. Проблемы и пути улучшения делового климата в регионах// Экономика региона. - 2016. -Т. 12, Вып. 1. - С. 150-161

20. Busch Ch., Barkema H.. Planned Luck: How Incubators Can Facilitate Serendipity for Nascent Entrepreneurs Through Fostering Network Embeddedness// Entrepreneurship Theory and Practice.-2020.- https://doi. org $/ 10.1177 \% 2$ F 1042258720915798 First Published April 8, 2020

21. Ebbers J.J. Network behavior and contractual relationships between entrepreneurs in business incubators//Entrepreneurship Theory and Practice.- . -2014. -Vol. 38(5). - P. $1159-1181$.

\section{Reference}

1. Amankwah-Amoah J., Khan Z., Woodc, G.(2020), COVID-19 and business failures: The paradoxes of experience, scale, and scope for theory and practice, European Management Journal, available at: https://doi.org/10.1016/j.emj.2020.09.002

2. Makysh S.B., Uruzbaeva N.A.(2019), Shagyn zhane orta biznesti damytudagy Қazakstannyn қarzhylyk 
ahualy, L.N.Gumilev atyndagy EUU habarshysynyn jekonomika serijasy, № 2, pp.127-132 (in Kazakh).

3.’Memlekettik statistika turaly" Kazakstan Respublikasynyn 2010 zhylgy 19 nauryzdagy Zany [Jelektronnyj resurs], available at: adilet.zan.kz. (in Kazakh).

4. Toksanova A.N. Osnovy predprinimatelskoy deyatelnosti: uchebnik / Toksanova. Aygul Nurpeisovna. - Astana : [Print-S]. 2007 . - 478 s (in Russian).

5. Small business management in the New Europe (1994), Ed. by A.A. Gibb, M. Rebernik, Maribor, Ekon, inst, $750 \mathrm{p}$.

6. Bates T.(1990). Entrepreneur Human Capital Inputs and Small Business Longevity, The Review of Economics and Statistics, Vol, 72, No 4, P. 551-559

7. Busch Ch., Barkema H. Luck P(2020) How Incubators Can Facilitate Serendipity for Nascent Entrepreneurs Through Fostering Network Embeddedness// Entrepreneurship Theory and Practice, https://doi.org/10.1177/1042258720915798

8. Kolesnikov A., Kolesnikova L.(1996), Malyj i srednij biznes: jevoljucija ponjatij i problema opredelenija, Vopr. Jekonomiki, № 7, pp. 46-58(in Russian).

9. Hippel E.( 1986), Lead Users. An Important Source of Novel Product Concepts, Management Science, Vol. 32, No 7,-pp.791-805

10. Beck T., Demirguc-Kunt A. (2006). Small and Medium-size enterprises: Access to finance as growth constraint// Journal of Banking \& Finance, Vol. 30.- No. 11.-P. 2931-2943.

11. Daxhammer K., et al.(2019), Development of a Strategic Business Model Framework for MultiSided Platforms to Ensure Sustainable Innovation in Small and Medium-Sized Enterprises, Procedia Manufacturing,Vol, 39, P. 1354-1362

12. Sabirova R.K., Dzhumaeva A.K., Utalieva R.S.(2020) Өzin-өzi zhumyspen kamtu: teorijalyқ negizderi men maseleleri, Jekonomika: strategija i praktika, № 1 (15), pp. 113-125(in Kazakh).
13. COVID-19 leads to dramatic unemployment, young people suffer the most. - URL: https://news. cgtn.com/news/2020-05-29/COVID-19-leads-todramatic-unemployment-young-people-suffer-themostQSUcPNPJ0Q/index.html(accessed: October 29, 2020).

14. Gosudarstvennaja programma podderzhki i razvitija biznesa «Dorozhnaja karta biznesa - 2025»// http://adilet.zan.kz/rus/docs/P1900000968

15. Doskalieva B.B. (2017), Jekonomika malogo i srednego biznesa goroda Almaty: problemy i perspektivy, Vestn. KazNU, Serija jekonomicheskaja, № 1, pp. 379-385 (in Russian).

16. Programma razvitija produktivnoj zanjatosti i massovogo predprinimatel'stva na 2017-2021 gody, utverzhdena Postanovleniem Pravitel'stva Respubliki Kazahstan ot 29 dekabrja 2016 goda № 919 [Jelektronnyj resurs], available at: adilet.zan.kz. (in Russian) (accessed: October 20, 2020).

17. Programma «Dorozhnaja karta biznesa 2020»(2010), Postanovlenie Pravitel'stva RK № 301 ot 13 aprelja 2010, [Jelektronnyj resurs], available at: adilet.zan.kz (in Russian)(accessed: October 20, 2020).

18. Daribaeva A.K., Kurmankulova N.Zh., Karbetova,Sh.R.(2018), Razvitie massovogo predprinimatel'stva v Kazahstane, Vestnik KarGU, Serija «Jekonomika», № 3(91), pp. 173-178 (in Russian).

19. Uruzbaeva N. A.( 2016), Problemy i puti uluchshenija delovogo klimata $\mathrm{V}$ regionah, Jekonomika regiona,T. 12, Vyp. 1, pp. 150-161(in Russian).

20. Busch Ch., Barkema H.(2020). Planned Luck: How Incubators Can Facilitate Serendipity for Nascent Entrepreneurs Through Fostering Network Embeddedness, Entrepreneurship Theory and Practice, https://doi.org/10.1177\%2F1042258720915798 First Published April 8, 2020

21. Ebbers J.J. (2014). Network behavior and contractual relationships between entrepreneurs in business incubators. Entrepreneurship Theory and Practice, 38 (5), 1159 - 1181. 


\section{Авторлар туралы мәліметтер}

Сабирова Р.К. - хат-хабаршы авторы, экономика ғылымдарының кандидаты, қауымдастырылған профессор, кафедра меңгерушісі, Х.Досмұхамедов атындағы Атырау университеті, КеАК, Атырау қ., Студенттер к-сі, 1, почта индексі 060011, 8(701)7266631, sabirovarysty@mail.ru, https://orcid.org/0000-00029947-6564 ResearcherID P7583-2014

Мусаева А.А. - экономика ғылымдарының кандидаты, қауымдастырылған профессор м.а., Х.Досмұхамедов атындағы Атырау университеті КеАҚ, Атырау қ., Студенттер к-сі, 1, почта индексі 060011, 8(702)8023552, aiman-mussayeva@mail.ru, https://orcid.org/0000-0002-5954-4665

Тажиденова А.P. - менеджмент магистрі, аға оқытушы, Х.Досмұхамедов атындағы Атырау университеті КеАҚ, Атырау қ., Студенттер к-сі, 1, почта индексі 060011, 8(701)2694333, ainuna-18@mail.ru, ttps://orcid. org/0000-0002-1281-7240

\section{Information about the authors}

Rysty Kuandikovna Sabirova - corresponding author, Candidate of Economic Sciences, Associate Professor, Kh. Dosmukhamedov Atyrau University, Atyrau, st. Student 1 zip code 060011, Head of Department 8(701)7266631, sabirovarysty@mail.ru, https://orcid.org/0000-0002-9947-6564 ResearcherID P7583-2014

Aiman Mussayeva - Candidate of Economic Sciences, Kh. Dosmukhamedov Atyrau University, Atyrau, st. Student 1 zip code 060011,8(702)8023552, aiman-mussayeva@mail.ru, https://orcid.org/0000-0002-5954-4665

Ainur Tazhidenova - Kh. Dosmukhamedov Atyrau University, Atyrau, st. Student 1 zip code 060011, 8(701)2694333, ainuna-18@mail.ru, ttps://orcid.org/0000-0002-1281-7240

Дата поступления рукописи: 01.11.2020

Прошла рецензирование: 17.02 .2021

Принято решение о публикации: 28.02.2021

Received: 01.11.2020

Reviewed: 17.02.2021

Accepted: 28.02.2021

Қарастыруға қабылданды: 01.11.2020

Рецензиялауды өтті: 17.02.2021

Жариялауга қабылданды: 28.02.2021 